\title{
65. The Sakawa Orogenic Cycle in the Amur Geosyncline.
}

\author{
By Teiichi Kobayashi. \\ (Comm. by T. KATo, M.I.A., June 12, 1942.)
}

Tetiaeff and his cooperators ${ }^{1)}$ brought about a notable advancement in the geology of Transbaikalia when they found a good display of marine Mesozoic formations. Remarkably enough, the stratigraphic succession of the Mesozoic and its bearing on the tectonics agree with those of the Japanese islands, especially of the Kitakami mountainland ${ }^{2}$ in many respects. This is the reason that I present a comment on their works from our side. The succession which the joint workers determined may be summarized as follows:

12) Inoceramus bearing Lower and Middle Cretaceous sandstone formation, about $1000 \mathrm{~m}$. thick.

11) Conglomerate formation of the Upper Jurassic to Lower Cretaceous age, measuring $120 \mathrm{~m}$. along the Turga and Gasimur rivers but, increasing in thickness as it proceeds towards the south till at length it attains $2500 \mathrm{~m}$. along the Onon and Borsia.

10) Callovio-Bathonian thick sandstone formation, about $1000 \mathrm{~m}$. thick, intercalating sandy clayslate and yielding Perisphinctes, etc.

9) Bajocio-Aelenian sandy clayslate formation, $600 \mathrm{~m}$. thick, containing Ceromya, Modiola, etc.

8) Aelenian clayslate formation, $120 \mathrm{~m}$. thick, containing arkose sandstone and yielding Belemnites, Lytoceras, Posidonomya, etc.

7) Upper Liassic formation containing Dactylioceras and other Molluscan fossils and composed mainly of conglomerate beds of 400 metres' thickness at one place but merges with shale beds of $50 \mathrm{~m}$. at another through sandstone beds of $180 \mathrm{~m}$.

6) Liassic sandy shale formation over $600 \mathrm{~m}$. thick, comprising Dactylioceras, Beaniceras and Aegoceras zones in descending order in the upper half and yielding pelecypods and plants in the lower; sandstone occurs in the middle part while shales in the basal part are thin-bedded.

5) Basal Liassic non-fossiliferous conglomerate bed $80 \mathrm{~m}$. thick.

4) Noric sandstone and shale formation containing Pseudomontis ochotica and its varieties.

3) Pseudomonotis scutiforme3) bearing Carnic (?) formation composed of sandstone in addition to clayslate.

2) Basal conglomerate bed of the Upper Triassic formation.

1) Thick Skyto-Anisic (?) formation composed of sandstone and shale in main but a limestone layer occurs in the lower part; base is unknown.

As in the Southern Kitakami Mountainland the basal conglomerate

1) M. Tetiaeff (1931), Neue Angaben über die Verbreitung mariner Trias in Transbaikalien. Bull. Geol. Prosp. Serv. USSR. 50; L. Kiparsova (1932) Contributions to the Stratigraphy of the Marine Trias of Eastern Transbaikalia. Trans. Geol. Prosp. Serv. USSR. fasc. 111 .

2) S. Mabuti (1933), Jurassic Stratigraphy, of the Southern Part of the Kitakami Mountainland, Northeast Japan. Proc. 11 (1935), Y. Inai and T. Takahasi (1940), On the Geology of the Southernmost Part of the Kitakami Mountainland. Contr. Inst. Geol. Pal. Tohoku Imp. Univ. Sendai No. 34; T. Shiida (1940), On the Geology of Kesenmachi and its Environs in Miyagi Prefecture. ibid. No. 33.

3) T. Kobayashi (1935), Einige nenue Triadische Bivalven aus der Innenzone Südwest-Japans. Japan. Jour. Geol. Geogr. vol. 12. 
of the Kochigatani series (2) overlies the Inai (1) with the Akiyoshi discordance in between. In the Turga basin the Jurassic formation lies on the granitic basement and this discordance shows the crustal movement of the Toyogadake phase. Furthermore it is to be remarked that as in Nippon, the Jurassic system in Transbaikalia consists of two major cycles of sedimentation the emergence between the two subsidences being called Hida. The upper part of the sixth formation is an equivalent of the Hosoura sandy shale; it is overlain by a conglomeratic bed (7) which roughly corresponds to the Aratozaki conglomeratic sandstone. Whether the Mano or Arato fauna is related to that of the eighth or ninth bed respectively is an interesting subject of a palaeontological study. The common occurrence of perisphinctids show that the thick sandstone (10) is approximate to the Samuraikama formation in age. It is noted that the occurrence of Seymourites ${ }^{1)}$ in a bed below the perisphinctid zone in the Tetori series indicates an inflow of the northern sea on the inner side of Nippon.

At Ouliatoui along the lower Unda river a conglomerate bed at the base of the Jurassic formation containing volcanic material is found overlain by beds of shale and sandstone, 1700 to $1800 \mathrm{~m}$. thick, and then comes above them the next conglomerate of 500 metres' thickness which contains reworked pebbles of the Jurassic rocks. Sandy shale beds 250 to $300 \mathrm{~m}$. thick, lie at the top of this section. If the lower conglomerate is upper Liassic, the upper one is an equivalent of the eleventh conglomerate formation the thickness of which laterally changes from 120 to $2500 \mathrm{~m}$. Judging from these facts the conglomerate formation in the interval from late Jurassic to early Cretaceous must be a sediment synorogenic with the Oga phase through which movement the periphery of the basin was emerged with the result that the lower part of the formation was eroded.

Beside the marine facies there are two continental facies called Algatchi and Estheria, of which the latter is tuffaceous but not the former. While the south side of the Upper Gasimur is occupied by the marine facies, there is a good display of the Algatchi containing plant beds and coal seams on the other side. It can be classified into the following four series:

Upper Gasimur series; $1500 \mathrm{~m}$. thick, composed of conglomerate, sandstone and clayslate in alternation.

Bochinsk series, 1000 to $1500 \mathrm{~m}$. thick, consisting of arkose and sandstone.

Basanow conglomerate series measuring 1400 to 1600 metres at the thickest but wedging out easterly.

Akatui series, $1000 \mathrm{~m}$. thick, composed of arkose, sandstone and clayslate.

The Algatchi flora comprising Cladophlebis haiburnensis, C. nebbensis and several others is certainly more related to the Mongugai than to the Nikan, and the age of the Mine floral group to which it belongs, extends from Liassic to Carno-Noric as discussed on former occasions. Therefore the Upper Gasimur must be correlated to the upper Liassic conglomerate beds of the marine Jura and the Basanow to the lower

1) T. Kobayashi (1935), Contributions to the Mesozoic Faunas of Japan. Jour. Geol. Soc. Japan, vol. 42. 
Liassic ones. Consequently the Akatui must be heterophic from but synchronous with the Kochigatani series.

The tuffaceous facies called Estheria-Jura is distributed from the Turga toward the southeast beyond the Argun into Manchoukuo. There are two conglomerate beds in the Argun section in the east and three conglomerate beds in the Turga section in the west. If the lower ones in the two sections are admitted to correlate with each other, the generalized section is as follows:

h) Upper basic volcanic rocks and their tuffs.

g) Selinda (?) conglomerate and sandstone, partly tuffaceous.

f) Turga alternations of shale, sandstone and tuff containing Estheria.middendorffi and Lycoptera middendorffi.

e) Middle volcanic rocks varying from acidic to basic, and their tuffs besides sandstone containing Czekanowskia rigida.

d) Alternations of coarse sandstone and conglomerate.

c) Lower volcanics of Belesaja comprising porphyry, porphyrite and their tuffs in addition to sandstone containing Equisetites sarrani.

b) Karabon sandstone, shale and tuff formation yielding Estheria reticulata, E. transbaikalia, ostracods and plants.

a) Tuff, conglomerate and shale containing Estheria cfr. hectori; Triassic rocks contained in the basal conglomerate:

It is quite interesting to see a remarkable coincidence of this succession with that of the Mesozoic formations in the Peipiao coal-field which C. Rin determined. He classified in descending order into red beds (g), Lycoptera bearing paper shale (f), upper volcanics (e), conglomerate and shale (d), lower volcanic (c) and tuff $(a-b)$. The last is underlain by the Peipiao coal measures above and volcanics below which are members of the Daido series. From the vertical change of facies in the Estheria-Jura it is suggested that its lower and upper conglomerates $(\mathrm{a}, \mathrm{g})$ may be Toarcian and Wealden respectively.

Together with the Palaeozoic formations and metamorphic rocks ${ }^{1)}$, all of these Mesozoic formations are strongly disturbed by the Sakawa orogeneses. Among the three facies only the Estheria-Jura is found to be autochthonous. The Daurski and Schilka ranges are folded mountains and the Algatchi formation is exposed as a Fenster; many thrusts found along the Kuenga; two Decken, the upper one composed of Palaeozoic rocks and the lower of marine Liassic, are piled up on the autochthonous Estheria-Jura in the Turga and Onon tributaries; and similarly the autochthonous Estheria-Jura in the Upper Borsia is thrust by the Algatchi and the latter in turn by a mass of the Palaeozoic formation and granitic gneiss. Furthermore it is known that the Estheria-Jura is imbricated in the environs of NertschinskSawood at about the middle course of the Argun. The northwestern side is generally thrust or overthrust from the other side in eastern Transbaikalia.

1) M. Tetiaeff, J. M. Schönmann, J. P. Dengin, A. L. Lissowski, K. G. WoinowskiKrieger and E. A. Presnjakow (1931). Materialen zur Geologie von Ost-Transbaikalien. Trans. Geol. Props. Serv. USSR. fasc. 37; W. N. Rudnew (1931), Geologische Untersuchungen Transbaikalien, (St. Scharasun, Dyrbylkei und Dorf Soktui). ibid. fasc. 152. If the metamorphosed green rocks are older Palaeozoic they may be products of an intrageosynclinal volcanism of the Mongolian geosyncline. 


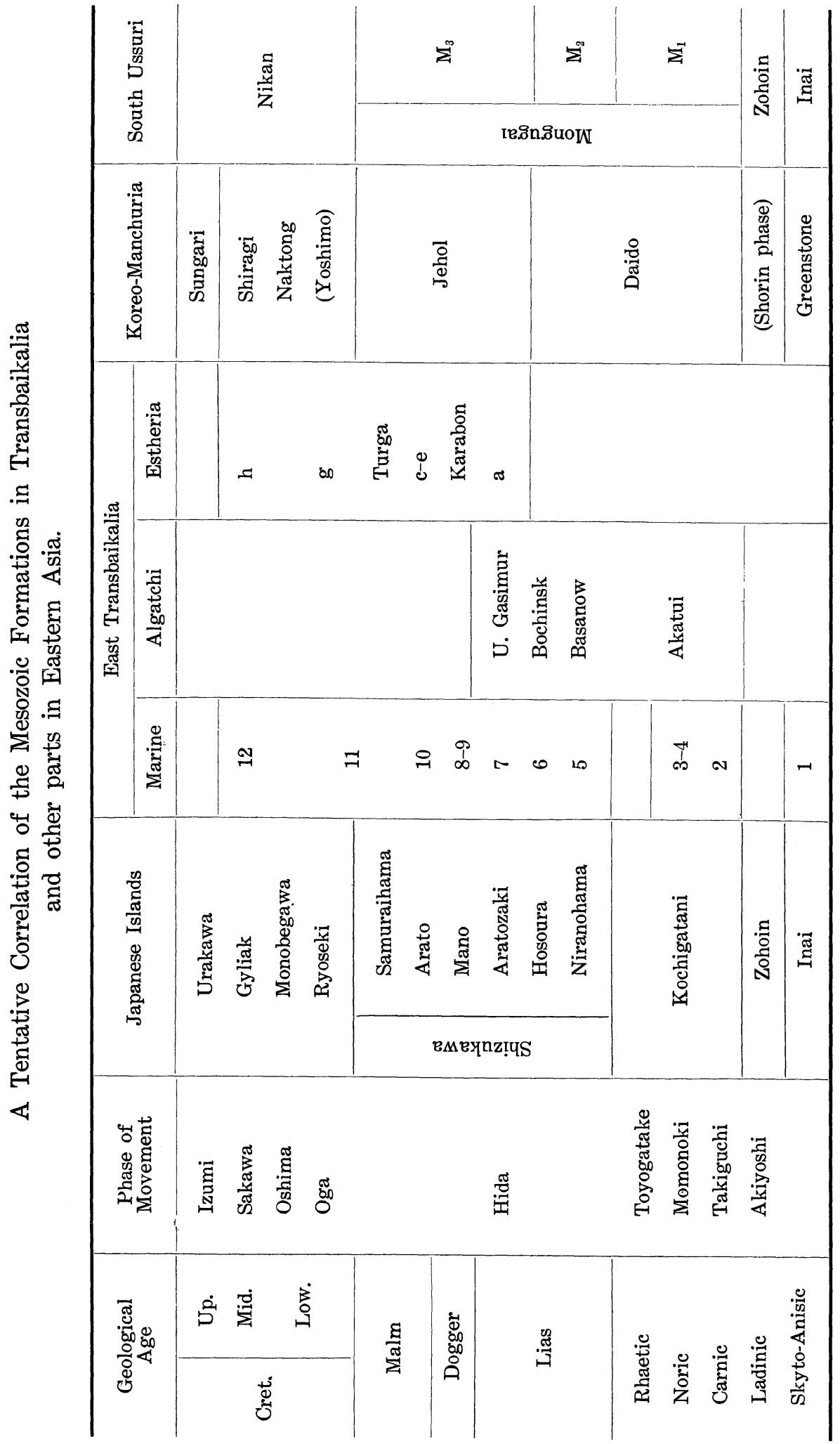


The orogeneses were accompanied by the mesoplutonism as seen in granite or porphyry masses exposed on the divide between the Turga and Borsia and in some others in the Gasimur and Argun tributaries extending parallel to the above mentioned masses. They are Jurassic or post-Jurassic intrusives. This Orogen however does not belong to the Alpine type as Schönmann at first considered, because this Orogen appears to have no metamorphosed axis ${ }^{1}$.

According to him the Orogen extends for a distance of $150 \mathrm{~km}$. from eastern Transbaikalia into northeastern Mongolia ${ }^{2)}$, but it does not extend very far on the south or southeast side, because the Toyama series of Chalai-nor which contains plants of the middle Jurassic age according to Toyama and $\mathrm{Oishi}^{3}$, is not much folded, though flexured by the Grabensenkung. The Jehol-Köngsang series in Hokang coal-field in eastern Manchoukuo forms a monocline which is cut by a mesh of faults $^{4)}$; the Tsetsenwan in Mongolia is folded, but is not comparable with the Mammo and older formations in degree of folding. Thus it is quite certain that the south side of the Amur geosyncline which forms the floor of these Mesozoic formations became rigid and stable by the Akiyoshi orogenic cycle, though some parts of it may have been still labile.

The Amur mobile zone along the junction between the Altenscheitel and Mammoiden is probably a subgeosyncline in kind where the sea repeatedly invaded since the late Triassic period. Lately Woronez ${ }^{5)}$ discovered Halorella in a Bureya tribulatary ; Upper Triassic marine formation of the Uda valley, Jurassic one of the Upper Bureya and other Mesozoic ones of the Uda-land and the lower Amur region have long been known. Although little is known of their structure, Jurassic or post-Jurassic granitic masses are known to exist in the Seja and Amagun tributaries and in the Alski range of Udaland.

As discussed already ${ }^{6}$, the mouth of the Amur embayment was closed by waves of folding somtime in the late Gyliakian or early Urakawan period, and thus the Seja and Sungari fossil-lakes came into being, and there the Sungari series as deposited. The subhorizontal Ibin (伊敏) formation may be another sediment in a lake on the west

1) A. V. Voline (1932), Sur les granites postjurassiques dans la partie sudoccidentale de la Transbaikalie. Mém. Soc. Russ. de Minér, vol. 61; W. Melioranski (1934), On the age of the young granites in northeastern district. Bull. Geol. Prosp. Serv. USSR. fasc. 51 .

2) On account of the thrusts directed to the high Kraton this Orogen agrees with the Yokusen Orogen. Its structure however appears more complicated, the complication probably depending upon the structure of the Amur geosyncline. This was quite complicated, because it is a product of the Akiyoshi orogeneses.

3) G. M. Schönmann (1937), Sur la rapport entre le variscides et les mésozoides en Transbaikalie dans la région de l'Amour et en Mongolie nordorientale. Abstracts of Papers XVIII. Intern. Geol. Cong.

4) S. Toyama and S. Oishi (1935), Notes on Some Jurassic Plants from Chalainor, Prov., North Hsingan, Manchoukuo. Jour. Fac. Sci., Hokkaido Imp. Univ. ser. 4, vol. 3, no. 10.

5) H.C. Tan (1924), Geology of the Hokang Coal-field, Heilung-Kiang. Bull. Geol. Surv. China, no. 6.

6) N. Polutoff (1940), Russland in Geologische Jahresberichte, II Bd., Abt. B. 
side of the Great Khingan range. Thus, it can be recognized that the Sakawa cycle was closed by the early Urakawan. Because the Mammoiden was completely fused with the Altenscheitel by the Amuriden, the ensuing development of the whole oronized terrain was an anoronization, such as Schollenbewegung and effusions of plateau basalt.

As noted by Dodylevsky and Kiparsova ${ }^{1}$ the Inai and Kochigatani series are extensive in Northeastern Asia while the Ladinic formation is almost completely missing, showing that there was a post-orogenic emergence in the Akiyoshi phase which corresponds roughly to the Shorin $^{2)}$ phase in the Koreo-Manchourian land. Therefore it is appropriate to divide the tectonic history of this part of Asia into two cycles at this age, instead of combining the steps of developments from late Palaeozoic to late Mesozøic in one cycle as did Schönmann and Lazarev ${ }^{3)}$. From the tectogenetical standpoint the older or Akiyoshi cycle means the oronization of the Mongolian major and primary geosyncline whereas the Sakawa does that of the Amur minor and secondary geosyncline. I agree however with Schönmann and some others in that the thrustings of the Amuriden and Yenshaniden were directed to the opposite directions.

1) See the palaeogeographic map on page 83 in this volume.

2) L. Kiparsova (1936), Upper Triassic Pelecypods from the Kolyma-Indigirka Land. Trans. Arct. Inst. vol. 30 ; L. Kiparsova (1937), Fauna of the Triassic deposits of the Arctic Regions of the Sovient Union. Trans. Arct. Inst. vol. 31 ; Y. I. Dodylevsky and L. D. Kiparsova (1937), Stratigraphy of the Mesozoic Deposits in the Arctic Region of the USSR. Abstracts of Papers, XVII. Intern. Geol. Cong.

3) T. Kobayashi (1930), The Significance of the Unconformity at the Base of the Daido Formation. Jour. Geol. Soc. Tokyo, vol. 37.

4) G. M. Schönmann (1937), Les Cycles de plissement dans l'est de l'Asie en comparasion de ceux de l'Europe. Abstracts of Papers XVII. Intern. Geol. Cong.; A.Z. Lazarev. (1937), Main stages of development of the folded structure of the Far East Region. ibid. 